\title{
Sugars of Great Price
}

\section{Some Rare Varieties, of Special Uses, Worth More Than Their Weight in Bullion}

\author{
By James H. Collins
}

$\$$ on the market for those yes, it is now Not many people are direct buyers, yet everybody buys it indirectly.

It is called "trehalose," one of the scarcest and most expensive of a very interesting line of products developed in re cent years by American chemists - the rare sugars. Put up in little ten-gram packages at $\$ 10$, its price in gold for that quantity weighs about 240 grains, and ten grams of sugar 155 grains. It is worth virtually one and a half times its weight in gold. Even by the troy pound, it costs more than 12 ounces of gold.

This particular rare sugar was originally known as "mycose," or mushroom sugar, because it is found in ergot, a microscopic fungus. Berthelot, the great French chemist, first prepared it from trehala manna in 1859 , and some idea of its scarcity is gained when one knows that this manna, the excretion of an insect found in Persia and Turkey in the form of cocoons, consists chiefly of starch, sugar and gum derived from a species of globe thistle upon which the insect feeds. Within the last two years, it has been found in the resurrection plant that grows abundantly in our Southwestern states. This is the familiar plant sold as a curiosity, apparently dead, but coming to life when placed in water. Containing two per cent of trehalose, American chemists found a more abundant material from which to make it commercially-abundant in the sense that two or three pounds of this sugar yearly will take care of all their customers.

What does the stuff look like-and what is it used for? Just a fine, white crystalline powder, sweetish but not sweet in taste, and, like all the rare sugars, used in the delicate identification work of the bacteriologists.

We all speak familiarly of bacteria. There is the old joke about them being called germs in Germany, parasites in France and microbes in Ireland. However, even to the bacteriologist, the majority of them are invisible under the highest power microscope. If we first think of the infinite variety of plants in a tropical jungle and a botanist turned loose to identify and classify them, and then think of the bacteria as a microscopic and sub-microscopic botanical world, as infinite in its variety, and the bacteriologist turned loose to identify a few thousand of them in one short life-then we get the bacteria into some perspective.

To identify many of them, the bacteriologist must find something upon which they will grow, and they alone, for he cannot see them. Planting his particular bacteria upon some "culture" like one of the rare sugars, which is their congenial garden soil, he raises an invisible crop. Injected into a rabbit or a guinea pig, this culture produces symptoms associated with that particular kind of bacteria and the identification is complete.

Even were it cheap, trehalose would not do for home brew, because it will not ferment with ordinary brewers' or bakers' yeast; but certain wild yeasts are said to ferment in it, and some of those wild yeasts-which are bacteria-may be of great importance to man. If benign, they will perhaps improve his products, enrich his diet, or cure his maladies, and if they happen to be malign, they will spoil his happen to be malign, they will spoil his
goods, or crops, make him sick-even kill him. A rare substance like trehalose may be the only means by which they can be studied. Because pure trehalose has been almost unobtainable until now, very little bacteriological research has been done with it, and so it opens up a virgin field to the scientific investigator.

You will hardly buy "raffinose" at $\$ 150$ a pound, or "rhamnose" at $\$ 100$, or any other of a dozen or more rare sugars ranging down to "saccharose" at $\$ 1.35$ which is cheap. Because a pound of ordinary table sugar made chemically pure for bacteriological purposes costs $\$ 1.50$. But

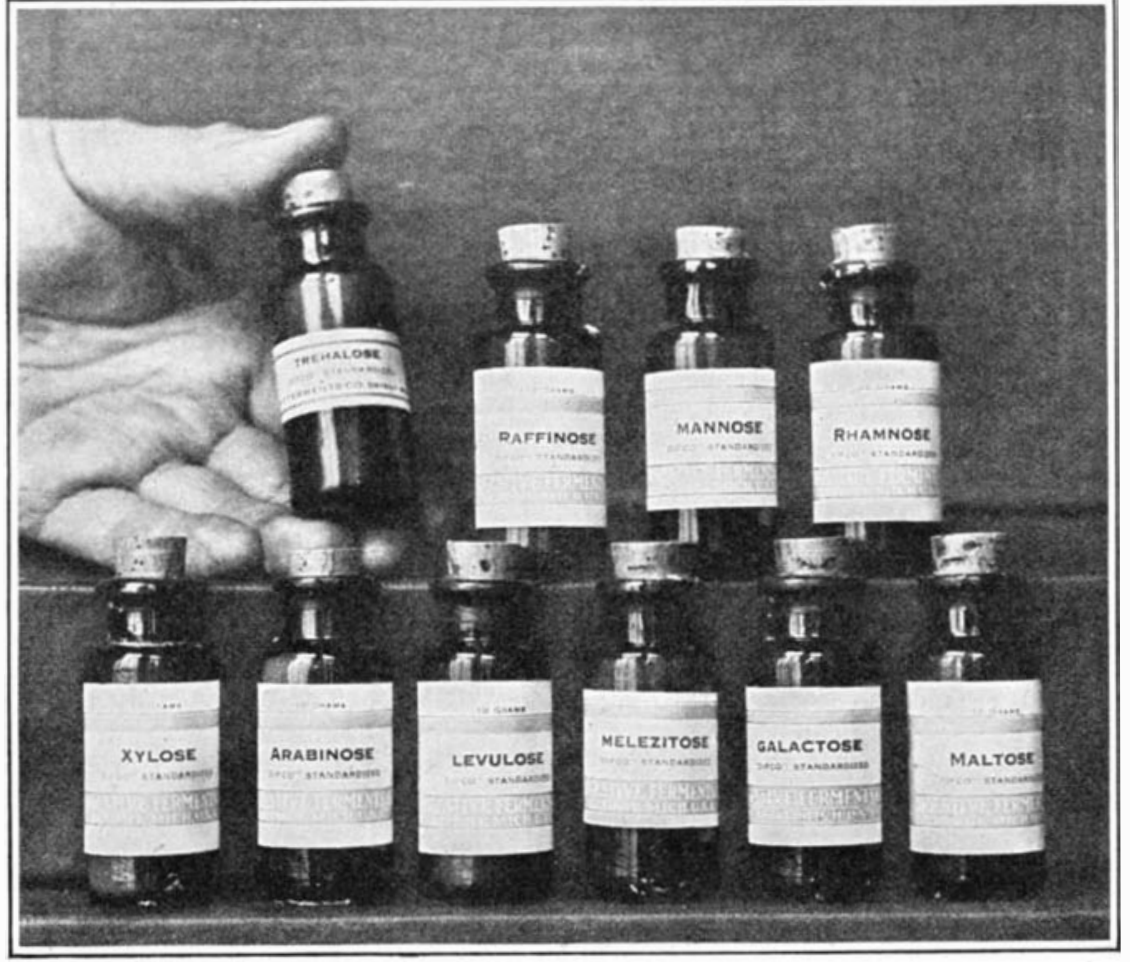

Ten of the rarest sugars. The group is worth thirty dollars, which would buy a quarter-ton of ordinary sweetener of the rare sugars were already known as laboratory substances, but methods of isolating them were vague and uncertain. In most cases, they had not been rendered pure, and in no case had they been brought to the point of manufacture and made available for scientific workers. Better methods were devised for isolating these known sugars, and later making them in quantity. Other rare sugars were discovered by members of Dr. Hudson's staff. One young chemistry B.S., who had gone into the laboratory right after taking his degree, found these rare sugars so interesting that he specialized in them, carving out a profession for himself. The government's carbohydrate laboratory published its results and went back to practical sugar-bowl problems, most of the chemists participating in the rare sugar hunt leaving the government service for work far from rare sugar fields. But T. Swann Harding, the young B.S. who found these rare sugars fascinating, kept on seeking ways of manufacturing them, and attracted the attention of a pharmaceutical concern far-sighted enough to undertake Sugar-the table variety-versus trehalose

indirectly you are buying these products as part of the scientific research work you supp

The rare sugars have been developed chiefly through the scientific research of American chemists, and they are entitled to the sole credit for producing them commercially. Before 1914, German chemists had failed to produce them in chemical purity on a scientific scalesome of them they couldn't produce at all.

American research in this little-known field, was begun by chemists working for Uncle Sam. Their job, at the outset, was to study problems connected with the production of every-day sugar as we know it in the sugar bowl, and in syrup. With a number of assistants, Dr. C. S. Hudson began this work seven or eight years ago in the carbohydrate laboratory of the United States Bureau of Chemistry. Cane syrup producers in the south were having trouble - people complained that their syrup frequently fermented or crystalized. There is an enzyme known as "invertase," which can be mixe with syrup to prevent that, provided it could be made cheap enough. It is found in many yeasts and other fungi, as well as pollen grains, beet root and other sources. It is a ferment or "enzyme." This work with invertase directed attention to the rare sugars, and the government chemists went after them, passing from
the study of practical problems to pure research. Some their commercial development. Today, Mr. Harding is not only the chief authority in his unique profession, but practically the only specialist in his line-to paraphrase Louis XIV, the profession, it is he!

"It is not a large nor an immensely profitable line yet," he says, "but for whatever it is worth I am itliving proof that a brain, no matter of how low horsepower, will get somewhere in eleven years of specialization."

As an outcome of his work the past three years, the chemical story of more than one rare sugar brought down to date winds up with a reference to his work.

In the sugar bowl is only one member of a large family of organic chemicals, known by the word "sugars." There are dozens of these, and new ones are being discovered every now and then. Like all organic chemicals, they occur in systematic groups, and these groups are named according to the number of carbon atoms occurring in the molecule. Thus a "hexose" is so called because it has six atoms of carbon.

The majority of the rare sugars are rare indeed. They have been made in the laboratory in minute quantities, studied to some extent, but remain chemical curiosities. About fifteen of the rare sugars already have some commercial importance, and others will eventually be added. For rare sugars are constantly being studied chemically and bacteriologically, and new uses found for them every little while. They are in constant demand in the scientific world, though they were never available commercially until two or three years ago.

The first rare sugar studied by Uncle Sam's chemists was "raffinose," which is the second most expensive at $\$ 150$ a pound. It really consists of three simpler sugars and can be partially broken down to "melibiose," and "levulose," or wholly broken down to "galactose," "glucose" and "levulose." It was first found in a eucalyptus, described by Mudie in 1832. Johnston first made the sugar in 1843, calling it eucalyptus sugar. Loiseau crystalized it from sugar beet residues, calling it raffinose from the French word "to refine" in 1856. Ritthausen isolated it from cottonseed meal in 1884 , calling it "gossypose." A year later Tollens suggested that all these sugars were the same thing, and so it proved. Hudson and Harding evolved a method for making it in 1914, and Harding later derised a method of manufacturing it in commercial quantities. At $\$ 150$ a pound, the raffinose in our cottonseed meal alone would, in one year, more than pay off our national debt, for it is worth $\$ 30,000,000,000$. . But it would cost more than the national debt to extract it, and a few dozen pounds yearly are all the scientific world requires.

(Continued on page 362) 